\title{
Overview of Safety and Efficacy of Non-Viral Gene Transfer in Cartilage Tissue Engineering from the Worldview of Islam
}

\author{
Noorhidayah Md Nazir ${ }^{1}$ and Munirah Sha'ban ${ }^{2}$ \\ ${ }^{1}$ Department of Biomedical Science, Kulliyyah of Allied Health Sciences, International Islamic University \\ Malaysia (IIUM), Kuantan, Pahang Darul Makmur, Malaysia ${ }^{2}$ Department of Physical Rehabilitation Sciences, \\ Kulliyyah of Allied Health Sciences, International Islamic University Malaysia (IIUM), Kuantan, Pahang \\ Darul Makmur, Malaysia
}

\begin{abstract}
This paper examines the safety and efficacy of non-viral gene transfer in cartilage tissue engineering (TE) from the worldview of Islam. The first clinical trial treating adenosine deaminase deficient patients conducted in 1990 has triggered the development of gene transfer technology. The potential of gene transfer is further explored in TE field with the hope that it could prosper the regenerative medicine application. However, ethical issues become important when it comes to application of new treatment modalities, primarily in gene transfer because of genetic modification influences the basis of life - the DNA. Besides ethical issue, the application of gene transfer in treating diseases also attract views from religious context. The questions on the techniques to administer the gene in human, social acceptance of genetically modified cell and adverse effects from it are still debatable and unresolved. Apart from that dilemma, both safety and efficacy issues are raised due to the scientific uncertainty and social perception of the technology. Despite countless number of encouraging findings and recommendations by the proponents of the technology, gene transfer is currently available only in the research setting. The established guidelines are used to complement and provide the necessary foundations in discussing the aspects involved in the incorporation of gene transfer with cartilage TE. Relevant Islamic input are identified and aligned to those particular guidelines. It is hoped that the integration of Islamic inputs in the existing guidelines could suggest the safest approach in treating cartilage degenerative disease through gene transfer and TE.
\end{abstract}

KEYWORDS: Gene Transfer, Cartilage Tissue Engineering, Safety, Efficacy, Islamic Worldview

\section{INTRODUCTION}

Advances in biomedical technology has enhanced the treatment for tissue degeneration and organ failure and thus improve patients' outcome. ${ }^{1}$ One of the major achievements is the practice of tissue/organ transplantation or replacement using surgical interventions as the treatment modality. Nevertheless, it is noted that surgical procedures have a few drawbacks. Massive blood or tissue loss may happen during the process. ${ }^{2}$ While it is wellknown that many patients experience tissue/organ rejection due to incompatibility of donor tissue/organ, many other recipients require a number of immunosuppressant drugs to make it work. ${ }^{3}$ Critical shortage of living donor tissue/organ is another major setback in this practice and it is indeed worrisome. Coupled with risk of infection, issues in tissue/organ transplantation have become more complex and leave uncertain future for the practice. Hence, alternative treatment approaches are essential in this case.

Munirah Sha'ban

Department of Physical Rehabilitation Sciences, Kulliyyah of Allied Health Sciences, International islamic University Malaysia (IIUM), Kuantan Campus.

Email:munirahshaban@iium.edu.my
Tissue engineering pioneered by Langer and Vacanti ${ }^{4}$ is an interdisciplinary field in regenerative medicine that offers an alternative in facilitating tissue regeneration. This biomedical technology has evolved over the past three decades to overcome unresolved issues in tissue/organ donation and transplantation. Artificial urinary bladder is one of the notable outcome ${ }^{5}$ in this burgeoning field. The outcome triggers further regenerative medicine development. Researches in tissue regenerative involving heart valve ${ }^{6}$ cartilage ${ }^{7-9}$ skin, ${ }^{10,11}$ bone $^{12}$ and other structures are currently being explored and some encouraging findings are seen. The positive outcomes from these research could perhaps shed some lights in solving medical and health problems, reducing pain and possibly improving patient's life expectancy. While it can be appreciated that TE produces biological spare parts to restore and repair certain parts of the human body, gene transfer (better known as gene therapy) is another potential method or treatment approach that uses gene as the therapeutics biological repair agent. The first clinical trial was conducted in USA on 1990 and some positive findings were observed. ${ }^{13}$ From that point, numerous in-depth researches concerning gene therapy administration increased expeditiously for other medical conditions including the TE research field. 
This paper discusses a hybrid biotechnology namely the combination non-viral gene transfer and cartilage TE and its safety and efficacy issues. Cartilage TE has become more important and relevant because the number of patients who suffer from knee joint osteoarthritis or cartilage degeneration in Malaysia is increasing. The "wear and tear" cartilage in osteoarthritis causes the joints to become painful and stiff. It was reported that people who are over 65 years have the highest pain rate among the sufferers. ${ }^{14}$ Cartilage is a thin glossy white structure that articulates the end of the bones. Functional articular cartilage prevents or reduces friction between the bones. This highly organized connective tissue provides remarkable mechanical strength to knee joints and able to withstand heavy weight pressure. The avascular nature of cartilage makes it difficult to heal once it is injured. ${ }^{15}$ By having only one cell type namely chondrocyte (which is characterized by low mitotic activity), cartilage seems as an ideal candidate tissue to be engineered and enhanced through gene transfer.

Genetic engineering and its related outcomes such as genetically modified organisms (GMOs) and therapeutic gene transfer approaches are among popular topics that have been discussed openly. It is noted that views from the religious perspective on the application of therapeutic gene transfer are unavoidable.The social acceptance on the introduction of foreign gene into human body, and the level of understanding of the entire human genome are still debatable since its' first inception and even after the Human Genome Project has completed. Is gene transfer application guaranteed to bring no harm to human and works effectively without any adverse reactions? Have the safety and efficacy of the approach been properly measured? The assurance of applying the technique whether or not it is acceptable ethically along with the complete guideline triggered much discussion. There may be more than one acceptable answer to the above questions. This present paper attempts to examine the safety and efficacy of non-viral gene transfer in cartilage TE from the worldview of Islam.

Gene transfer definition, concept and its application in cartilage TE Gene transfer or gene therapy is a technique that delivers genetic information or gene of interest into the targeted cell. The idea of delivering DNA or gene into cells is for scientific purpose and based on the evidence that DNA controls all cellular activities. For this gene delivery, the DNA requires a unique vehicle or carrier. The assistance of carrier to transport DNA into cell is crucial since it has to pass through the cell membrane or barrier created by the phospholipid bilayer and the DNA itself. ${ }^{13}$ Naturally, the phospholipid bilayer repels against each other due to the negative charge possessed by the cell membrane structures.

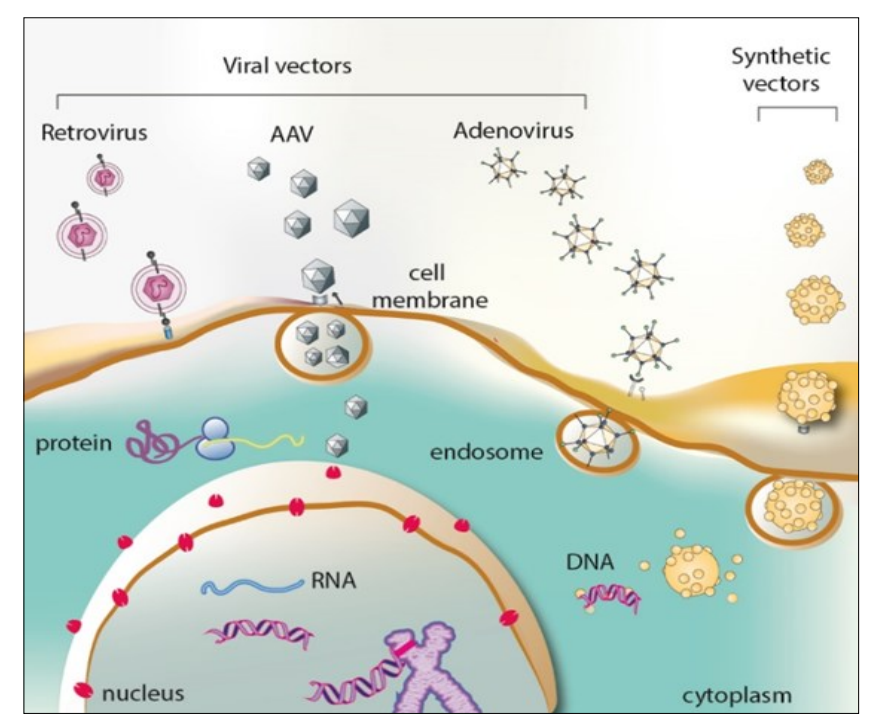

Figure 1: Overview of viral gene transfer and non-viral gene transfer approaches ${ }^{16}$

The transportation of the DNA or gene can be conducted by means of viral and non-viral approaches (see Figure 1). The viral approach applies the use of virus as a transportation vector of the target gene. Several types of vectors are frequently used to facilitate the delivery including adenovirus, adeno-associated virus, herpes virus, retro virus, lentivirus and many more. ${ }^{17}$ Basically, viral vector works by infecting and multiplying in a cell before the progeny is release by cell lysis, which then continue to infect the neighbouring cells. The small structure of the virus's plays an important role in helping the genetic information delivered effectively into the cells without using other external materials. This is because the virus itself acts as the carrier for the delivery. Unlike the viral method, the non-viral approach utilizes natural and synthetic materials to facilitate transportation of target gene into the cell. ${ }^{13}$ Among the numerous methods in this approach, lipofection method is the simplest way to deliver the gene. Principally, the method uses positively charged liposome to encapsulate negatively charged DNA and deliver the DNA into cell by merging with the membrane of the cell. Theoretically, the transported DNA can help to regulate and produce the desired proteins which then improves the function of the cell.

After conducting countless numbers of gene transfer studies, researchers identified the pros and cons of both viral and non-viral approaches. The latter is favoured by some researchers because of several advantages ${ }^{18-20}$ as this approach somehow triggers low immune response compared with viral approach which makes it suitable for human therapy. ${ }^{21}$ It was also observed that the non-viral approach caused low toxicity to cells. ${ }^{13,21,22}$ The ability to deliver high molecular weight DNA or gene is another reason why researchers prefer the nonviral technique although technically it provides less transfection efficiency. Besides, the small size nature of virus restrains or limit the amount of the 
genetic information that can be transported. These are among crucial characteristics considered by many scientists and clinicians for human gene therapy application (summarized in Table 1).

Table 1: The comparison of viral gene transfer and non-viral gene transfer

\begin{tabular}{ll}
\hline Viral gene transfer & $\begin{array}{l}\text { Non-viral gene } \\
\text { transfer }\end{array}$ \\
\hline $\begin{array}{l}\text { Able to deliver small } \\
\text { amount of genomic } \\
\text { Information }\end{array}$ & $\begin{array}{l}\text { Able to deliver large } \\
\text { amount of genetic } \\
\text { information }\end{array}$ \\
$\begin{array}{l}\text { Triggers high } \\
\text { immunotoxicity and } \\
\text { cytotoxicity }\end{array}$ & $\begin{array}{l}\text { Triggers low } \\
\text { immunotoxicity }\end{array}$ \\
$\begin{array}{l}\text { No external carrier } \\
\text { needed to deliver } \\
\text { DNA in cell }\end{array}$ & $\begin{array}{l}\text { Carrier needed to } \\
\text { deliver DNA in cell }\end{array}$ \\
High efficiency & Poor efficiency \\
\hline
\end{tabular}

The idea of delivering gene into cells perhaps triggered researchers to recognize the advantage of this advanced technology in combating human diseases. In the clinical application, gene therapy is likely to be used to treat genetic hereditary diseases.Principally, the gene delivered into the cell of patients will be transcribed and translated into therapeutic protein which perhaps could delay the side effect and also lessen the pain. This approach has been practiced some years ago and the first clinical trial on treating adenosine deaminase deficient, severe combined immunodeficiency (SCID) patients using gene therapy was conducted in USA in 1990 with some encouraging outcome. ${ }^{13}$ The procedure is performed by directly administering the potential therapeutic gene to the affected part or organ of the patient. Following that success, more studies using gene therapy have emerged including the therapeutic use of gene transfer in the spinal cord, ${ }^{22}$ articular cartilage, ${ }^{23}$ skin $^{24}$ and heart. ${ }^{25}$ This therapeutic approach is currently not applied in tissue engineering setup due to the possible uncontrolled risk towards the patients. Thus, testing the technique's application to the potential cells experimentally perhaps ensure safety and minimize unwanted effects before it can be conducted in human.

In TE, gene transfer is used to enhance cell properties. This is true especially if the technique uses diseased cells or samples such as in the case of osteoarthritis. Unlike the introduction of multiple exogenous growth factors into cells culture and its sophisticated formulation requirement, ${ }^{26}$ transfected gene directly regulates cells behaviour from within after one-time exposure. ${ }^{23,27,28}$ Quality of the source of the cell is one of the three important TE principles (or also known as the "TE triad"). The other TE principles include biomaterial scaffolds and biological signalling factors. ${ }^{29}$ While biomaterial scaffolds provide 3D surface attachment for cells growth, signalling factors are essential elements next to the cells. The elements include growth factors, or its gene and a dynamic bioreactor that mimics the internal microenvironment of human body. They help to facilitate proliferation and differentiation of cells and to maintain its' specific phenotype in culture. Numerous studies in cartilage TE demonstrated the importance of this interconnected TE principles in promoting chondrocytes proliferation and extracellular matrix production for tissue formation. ${ }^{29}$

In enhancing the source of cells, gene transfer method concerns with the selection of appropriate signalling molecules. Some potential genes or signalling molecules in cartilage TE include the transcriptional factor, Sex Determining Region $Y$ (SRY) -Box 9 (SOX9), ${ }^{23}$ transforming growth factor beta (TGF- $B)^{30}$ and insulin-like growth factor-I (IGFI). ${ }^{31}$ The role of these genes in chondrocyte growth have been explored extensively with several positive outcomes. The delivery of specific cartilaginous gene has been indicated to enhance the chondrogenic properties of cells and promote the formation of cartilage-like tissue in vitro. It is noted that most of the studies were carried out within a short term experimental setting. Factors such as limited research budget, type of cell source used and expectation of the researcher on the findings contribute in the "short term" experimentation.During research, tissue regeneration is observed through in vivo implantation in animal model and this may take up to months to obtain mature tissue sample for purpose of analysis. Thus, the assurance of a good and functioning tissue via gene transfer approach perhaps can be confirmed by having longer duration of implantation. The results from this short term experimental setup for cartilage morphology and its function seemed to be effective at this juncture. Much inference and arguments on the research findings and the effects of the application have been made. But in truth, the long term effect is still unknown and has yet to be uncovered in detail. Hence, the potential and the uncertainty of gene therapy should be explored comprehensively and addressed properly to ensure safety and efficacy before it is be applied to human.

\section{Safety and efficacy issues: Ethical concern from Western perspectives}

Besides promising technological advancement and numerous research mining for better treatment options, issues on the application of gene transfer in treating diseases attract ethical discussion. For many years, gene transfer studies are being conducted to find and optimize the less harmful gene administration packages with effective delivery. Yet, mixed findings obtained related to safety and efficacy of the approaches increase the uncertainty of gene transfer.Due to the inconclusive scientific findings coupled with 
negative response from the public on the technology itself, gene transfer for TE purpose is available in research setting only, regardless of numerous recommendations by the proponents of the technology. Despite the negative responses, some supporters are of the views that gene therapy is a promising way to prevent disease from affecting the life of a person and perhaps prolong the life-span.

The process of setting up gene therapy in human is not an easy to decide. It requires detailed information and several concerns that need to be addressed. Questions such as - why a particular disease (i.e. osteoarthritis) is suitable for gene therapy? Is there any alternatives besides the gene therapy? How effective is the gene delivery? What is the success rate for the gene expression in patients and what would be the suitable technical method for this? What are the adverse events?- are key inquiries when it comes to ethical approval application. ${ }^{32}$ There is one famous Latin phrase used in health care setting i.e. primum non (nil) nocere that meaning - first, do no harm. It is to say that, "given an existing problem, it may be better not to do something, or even to do nothing than to risk causing more harm than good." This is a strong reminder to all health care providers that they have to consider carefully any possible harm before any intervention. This term is frequently used when discussing the application of certain medical intervention that may carry obvious risk of harm, and with less chances of benefit. ${ }^{33}$

There is no doubt that gene therapy need to undergo strict procedures mainly because of the safety purpose. Several promising outcomes push the interested parties to take one step ahead i.e. to commercialise it. On one hand, it may be justified if the decision is made solely based on health economics. On the other hand, when it comes to human health, perhaps economy is not the ultimate determining factor in arriving at a decision. How the ethics committee assure smooth sailing of gene therapy especially when it is intended for commercialization since it is still in progress in the research setting for only the past decades?. ${ }^{34}$ Most importantly; How can researchers confirm the safety of patients by the use of gene delivery technique alone? Is gene delivery safety and efficacy in conformity with the list of cardinal values in bioethics namely autonomy, beneficence, justice, non-maleficence, human dignity and the sanctity of life?

Currently the social stand point of gene delivery in human specifically on genetically modified cell is still uncertain because researchers seem to overly control the nature of the cell and to certain extent, they change it. Besides, the fear of experiencing adverse effects post-treatment or long-term drawback is also what concerns most people. The problem arises when transfers of gene in cell is performed the inserted gene do not perform the intended function. Some of many questions arising are - will the cell (in the body) react to the delivered gene differently? Or, would the protein translated from the delivered gene secrete toxin to the cell? What would be a certainty is that the effects may vary from person to person particularly due to the dynamic nature of the connection and interaction between the cells. It must be noted that genetically, there are no two people are alike, even if they are identical twins. ${ }^{35}$

\section{Safety and efficacy issues: Ethical concern from Islamic worldview}

The basic principle in the Islamic value system is the belief system itself or the worldview. In Islam, the value system is governed by the Islamic law (Shariah Islamiyyah) within which the ethical value framework is constructed.There are some overlapping values between Islamic worldview and Western or other non-Islamic origin worldviews.

There are ongoing debates that seem to indicate that researchers are "playing God" especially when they are recommending and applying therapeutic technology to humans. ${ }^{36}$ The insertion of foreign gene into a human is argued to alter or violate the nature of the cell. This is perhaps based on the notion in the Holy Qur'an (67:3) that, "(And) who created seven heavens in layers. You do not see in the creation of the Most Merciful any inconsistency. So return (your) vision (to the sky); do you see any breaks?" All Allah's creations are created perfectly in which there is no way that man can possibly imitate the creation process, as stated in the Holy Qur'an; "Such is the Creation of Allah: now show Me what is there that others besides Him have created..." (31:11) and "... (Such is) the artistry of Allah, Who disposes of all things in perfect order" $(27: 88) .{ }^{37}$ Thus, some Muslims may perceive that the act of transferring the foreign genetic information for enhancement of cells is against disposition of humans.

The concern on the technique used on a patient has also been discussed whether or not the delivery method itself introduces harm more than benefit. The act of seeking treatment to improve quality of life is encouraged in Islam, but is it worth the risk? Although other medical techniques are also available. Other than the safety context, how sure are scientists of the regulation of the gene in human body i.e. does the gene stop expressing when the protein produced (by the gene) is enough for recovery, or will it continue to expresses throughout life of the patient? The overexpression of the gene may lead to adverse reaction and might threaten the life of the patient because of higher delivery efficacy do not promises excellent recovery process. It is noted that the element of uncertainty of the safety and efficacy is still unresolved. Research into these two aspects is ongoing. The authors themselves are in the midst of examining the safety and efficacy aspects of gene delivery and cartilage TE by means of empirical experiment using standard protocols outlined by the relevant regulatory body. Based on "sound logic" and Islamic 
teaching, health care provider has no right to recommend or administer any harmful material or substance to the patients. ${ }^{38}$ In one Hadith, the Prophet (PBUH) has been reported to have said: "There should be neither harming nor reciprocating harm" (Forty Nawawi, Hadith 32). This Hadith reminds health care provider to ensure that no harm is introduced in any intervention. The use of permissible materials should be along the lines as evident in the Holy Qur'an (7:157), “... and He makes for them good things lawful, and bad things forbidden ...".

Islam has outlined a comprehensive ethical framework as a guide to practice any form of human endeavours in an ethical and legal manner accepted by the Shari'ah. Based on the work of Professor Omar Hassan Kasule, ${ }^{39}$ it can be summarised that the ethical theory of Islam is based on the five higher objectives of the Law, Maqasid al Shari'ah namely protection of Diin (Hifdh al-Diin), protection of life (Hifdh al-Nafs), protection of progeny (Hifdh al-Nasl), protection of the mind (Hifdh al-'Aql) and protection of wealth (Hifdh al-Mal). The objective/goal (Maqasid) of Shari'ah is closely linked with the principles of Islamic law (Usul alFiqh) and the Islamic jurisprudence (Fiqh). The goal of this philosophy of the Laws is to answer the question "why" in order to equip the human's mind ('Aql) with the necessary understanding of the reason as well as the wisdom behind the command and the prohibition of Allah (SWT). Kasule ${ }^{39}$ added that many medical action must fulfil one of the above higher objectives if it is to be considered ethical. This is can perhaps be extended to gene transfer application in cartilage TE. That the gene transfer is to improve quality of cells so they will form new cartilage-like tissue which can restore the normal function of the joint and delay the progressive changes of osteoarthritis. Since the research is ongoing, it is too early for the authors to have definitive conclusion about the final outcome of this research.

Patients who suffer from knee joint problems and osteoarthritis have difficulties in performing 'Ibadah. Taking one example of the Maqasid, protection of Diin essentially involves 'Ibadah and 'Aqidah. Every human endeavour is a form of 'Ibadah. Kasule ${ }^{39}$ stated that medical treatment makes a direct contribution to 'lbadah by protecting and promoting good health so that the worshipper will have the energy to undertake all the responsibilities of 'Ibadah. The principal forms of physical 'Ibadah are the pillars of Islam namely prayer (Salah), fasting (Sawm); and pilgrimage (Hajj). On the one hand, a sick or a weak body may not be able to perform any of them. Physical movement during Salah, such as Ruku' (bow down) and Sujud (prostrations) require the individual to bend their knees in each Raka'at may be difficult to osteoarthritic sufferers. The cartilage that should "cushion" the bones during the joint movement has lost its ability, making the pain worsen. On the other hand, patients are unable to work or socialise and eventually left with an imbalance emotional state. Ultimately, the unstable psychological state may cause several other health problems including anxiety, depression. Thus, by treating the disease perhaps the action could reduce the stress of the patient which eventually brings back the positivity in the patient. In this aspect, the relevant medical treatment contributes to 'Ibadah. However, such noble intention shall not be based on or confused with utilitarianism for Islam has cautioned, the end does not justify the means. Reliable research and scientific evidence are required to validate the safety and efficacy of the medical treatment. While seeking for the best medical treatment is encouraged in Islam, human life is also valued in Islam. Protection of human life (Nafs) is one of the five higher objectives of the Shari'ah.

The principles of the Law, Qawa'id al-Shari'ah, are practical extensions and interpretations of the Maqasid. ${ }^{39}$ The Qawa'id include the principle of intention (Qa'idat al-Qasd), the principle of certainty (Qaidat al-Yaqeen), the principle of injury (Qaidat al-Dharar), the principle of hardship (Qaidat al-Mashaqqat) and the principle of custom or precedent (Qaidat al-Urf). The Maqasid and Qawaid are derived from the basic law but the detailed applications require further explanation or reasoning (ljtihad). There is nothing absolute except Allah SWT. The door for ljtihad must be left open because our life is dynamic and not stagnant especially when it comes to the advancement of science and technology nowadays. Kasule ${ }^{39}$ reports that healthcare providers in their conduct and decision making must be aware of the Maqasid and Qawaid to practice any treatment approaches in an ethical and legal way accepted by the Shari'ah. Any decision should be carefully deliberated by a qualified individual that follows Islamic law (Mujtahid) and experts in the field.

Although the Western perspectives and Islamic worldview are based on different sources and dimensions, some similar opinions in addressing the concerns of the administration of technology into human are present. The relevant authorities including government and non-governmental organization in healthcare field are aware about those issues and come out with several guidelines to regulate and monitor the rapid technological development in particularly in healthcare domain. This is discussed in the following section.

\section{Challenges in gene transfer for cartilage TE: Way forward}

It is important to understand the purpose of gene transfer and cartilage TE applications in human. It is anticipated that the incorporation of the two disciplines will facilitate the search for alternative treatment that perhaps could minimize the necessary intervention on the patient. The number of osteoarthritic patients increase everyday particularly among the aging population as joint pain limits and affects the daily including and 
religious activities. Tissue engineering research on cartilage regeneration is ongoing. Some initial findings indicate that gene transfer improves cartilage TE outcomes..$^{7-9}$ This may be an early indication that this hybrid technology can be used to improve the quality of life of patients. Theoretically, the delivery of therapeutic gene can enhance the cell's phenotypes and its behaviour by producing the intended protein in the cell. The process helps cell or tissue to retain the ability to perform its normal function. For example, the master regulator for chondrogenesis, SOX9 gene delivered in chondrocytes, transcribed and translated into proteins that can help to maintain and repair the cartilage function. It is also noted that cartilage regeneration remains a major challenge in orthopaedic due to its avascular nature. Although it makes a suitable candidate for gene delivery, the effectiveness of the technology in treating cartilage injuries and osteoarthritis is still uncertain.

Basic outline on pros and cons of both viral and nonviral gene transfer approaches are learnt from the obtained outcomes which perhaps could promote harm reduction and facilitate effective gene's delivery. It is noted that viral gene transfer approach is able to provide $40 \%$ to $50 \%$ transfection efficiency higher compared to non-viral approach that is around $35 \% .{ }^{40}$ However, based on the technical part of gene transfer, the authors suggest non-viral approach as a more suitable method for gene delivery in human based on the following reasons. This approach introduces less immune response to the patient because the use of material as vehicle for gene's delivery and the transported gene somehow does not integrate with recipient cell's genomic DNA. The "transient" or temporary nature of this approach contributes mild effect or less toxicity to the cell due to the diluted transgene expression after few generation. Past research shows that non-viral gene transfer generally causes less or no alteration on the cell's nature. The step taken is more on giving the cells an initial boost to retain and improve its function before regain stability to work on its own. This approach intent to introduce less harm as much as possible during the actual treatment. Hence, it is in-line with the Qawa'id al-Shar'iah wherein the obligation to introduce harmless or lesser harm intervention on living organism is noted. Allah SWT says; "if any one saved a life, it would be as if he saved the lives of the whole people" (The Holy Quran, 5:32) and "and make not your own hands contribute to (your) destruction" (The Holy Qur'an, 2:195). These Quranic verses serve as a prime guideline for Muslim researchers or clinical practitioners to introduce harmless treatment and save lives. ${ }^{36}$ Therefore, in Islam, no harsh or life threatening treatments are allowed. Kasule ${ }^{39}$ emphasises that, 'medical diagnosis and treatment must be based on certain evidence obtained from clinical examination and investigations. All medical procedures are considered permissible unless there is certain (Yaqeen) evidence to prove their prohibition.'
Although many advantages from non-viral gene transfer approach have been outlined, this approach has less efficiency or efficacy than the viral approach. Virus has excellent efficiency because it can easily infect the cell without having to subscribe for additional components to integrate into the DNA of the host cell. However, the resulting immune response, mutation and high toxicity level makes it inappropriate method for human gene therapy. The use of virus is quite controversial because of the fatality of the clinical trial of first gene therapy due to inflammatory reaction towards adenovirus. ${ }^{20}$ It is for this particular reason, the lesser efficacy of the non-viral system is ignored by researchers in finding the safer gene therapy treatment. Somehow, excellent efficiency does not guarantee excellent recovery process. Guidelines have been carefully drafted to avoid any unwanted clinical outcome.

Many regulations have been established as guidelines to prevent any misconduct activities by researchers. A strict regulation by the good laboratory practice (GLP) will eventually help the researcher to prepare superior quality genetically modified cell for clinical application. The establishment of important regulatory bodies and its regulations in Malaysia such as National Biosafety Board (NBB), Cell and Gene Therapy Products (CGTPs), Good Clinical Practice (GCP) and Good Manufacturing Practice (GMP) is noted. Although the guidelines are not specifically for TE application, these guidelines provide necessary foundations in discussing biosafety and biosecurity issues of the gene transfer and cartilage TE.Observation, in Malaysia show the implementation of the guidelines are still in early stage. However, the existence of the regulation is strongly suggested because of the purpose of the regulation itself is to reduce risks and minimize modification of living organisms. The intended experimental protocol has to undergo several stages of ethical application procedures before researchers can start working on the idea.

Obviously the implemented regulation helps to protect "originality" of the cell since all living organisms are the flawless creation by Allah SWT. Researchers utilize the readily available sources and not creating anything by any means. For example, in cartilage TE itself uses chondrocytes or stem cells for the regeneration of new cartilage tissue. Therefore, playing God or violating the "work" of God perhaps is not an issue in this case. Besides, the advancement of gene transfer technology and cartilage TE is part and parcel of knowledge acquisition. Muslims are encouraged to use their intellect to explore for ways to alleviate pain and suffering. ${ }^{41}$ Science should be used as a tool to increase our faith provided it does not dissociate human from the Creator.

In the clinical setting, the gene transfer procedure must first have approval from the institutional research and ethical committee. The approved procedure is only conducted upon consenting patients who have been briefed on every aspects of 
the application from the health care provider. Patients recruitment must be carried out in accordance with inclusion and exclusion criteria agreed upon experts in the field. Patients must be sane and are able to make their own decision regarding the treatment. This aspect must be observed carefully in order to justify that the established regulations are not contravening any human right. Every detail of the methods and materials used must be properly documented for future reference. Any adverse events or unwanted reactions must be recorded so the delivery can be improved further. In humble opinion of this author the potential gene regulation must be studied and monitored accordingly because it has yet to be understood completely.

Malaysia's Ministry of Health and Ministry of Higher Education have drafted and published the second edition of clinical practice guideline for management of osteoarthritis in $2013 .{ }^{42}$ This guideline will be reviewed in 2017 and it unfortunately shows that the clinical and scientific communities are committed in treating diseases. However, details of the process involved have not reached the public as it should be. Perhaps the public should be made aware of the guideline. Publicity through mass and social media is important. The public should not be left to judge gene transfer negatively without having enough information on the potential benefit of the technique. This is also applies to newly engineered tissues which experience relatively high demand, yet the research progresses have been decelerated due to numerous ethical and religious issues. ${ }^{43}$

In Islam, ethical concerns are guided by the Holy Qur'an and Hadith. Muslims are encouraged to seek treatments for any diseases to improve a person's life quality. Abu Hurayrah narrates that the Messenger of Allah SWT said; "there is no disease that Allah has created, except that He also has created its remedy" (Sahih Bukhari, 7; 582). ${ }^{44}$ It can be appreciated that Islam encourages us to explore different techniques in seeking the best treatment as long as it is in-line with the Shari'ah and in conformity with the guideline established by experts in the field. In the Holy Qur'an, "They said: "Glory to Thee, of knowledge We have none, save what Thou Hast taught us: In truth it is Thou Who art perfect in knowledge and wisdom."” (The Holy Qur'an, 2:32)

\section{CONCLUSION}

The safety and efficacy issues in gene transfer for cartilage TE have been presented herein. Based on the previous research findings, the pros and cons of both viral and non-viral gene transfer approaches from technical point of view are widely reported. Nowadays, the decisions made by researchers are solely based on the hypothesis, findings and establish ethical regulations. Apparently, the established guidelines have overlapping values with what Islam is championing although no official integration between them was observed. In Islam, the establishment of ethical aspect is governed by the Islamic law (Shariah Islamiyyah). This existed systematic organization consist of experts (Mujtahid) which help in assisting the finding of the solution that suits best depending on the situation (ljtihad).

However, the "playing God" issue regarding on the technology application for disease treatment to human are always going to be raised. The continuous arguments on the technology utilization might alters the nature of the cell which is against the law of nature and trying to replace God are endless. In the end, the true intention of using the technology for treating disease is important. This is because, the daily activities of patients become more challenging if the condition is left untreated, especially during performing 'Ibadah.

Islam encourages us to explore different techniques in seeking the best treatment as long as the researcher follows the Shari'ah and guideline established by experts in the field. Thus, gene transfer and cartilage TE are also considered as the act of seeking treatment. Furthermore, both gene transfer and cartilage TE utilize the available sources created by Allah SWT for the purpose of new tissue regeneration.

The Malaysian government is aware about the development of the technologies and its application in clinical aspect which is shown by the existence of the guidelines and regulations. Yet, the information is not properly conveyed to the public which lead to a communication gap. Social and religious acceptance are equally crucial for future development of the technologies in Malaysia. More research and discussion should be done in order to suggest the safest and efficient approach in treating cartilage degeneration disease through gene transfer technology.

\section{ACKNOWLEDGEMENT}

The authors thank the Kulliyyah of Allied Health Sciences, International Islamic University Malaysia, Kuantan Campus and Ministry of Science, Technology and Innovation (MOSTI) for providing Science Fund (SF14-012-0062) and Ministry of Higher Education (MOHE) for providing Transdisciplinary Research Grant Scheme (TRGS16-02-002-0002).

\section{REFERENCES}

1. World Health Organization [online]. Available at:

http://www.who.int/chp/topics/rheumatic/e n/. Accessed September 28, 2016

2. Prasad N, Padmanabhan V, Mullaji A. Blood loss in total knee arthroplasty: an analysis of risk factors. International Orthopaedics. 2007; 31(1): 39-44

3. Watson CJE, Dark JH. Organ transplantation: historical perspective and current practice. British Journal of Anaesthesia. 2012; 108(suppl 
1): $i 29-i 42$

4. Langer R, Vacanti JP. Tissue Engineering. Science. 1993; 260(5110): 920-926

5. Atala A. Tissue engineering of human bladder. British Medical Bulletin. 2011; 97(1): 81-104

6. Vesely I. Heart Valve Tissue Engineering. Circulation Research. 2005; 97(8): 743-755

7. Munirah S, Kim SH, Ruszymah BHI, Khang G. The use of fibrin and poly(lactic-co-glycolic acid) hybrid scaffold for articular cartilage tissue engineering: An in vivo analysis. European Cells and Materials. 2008; 15: 41-52

8. Munirah S, Samsudin OC, Aminuddin BS, Ruszymah BHI. Expansion of human articular chondrocytes and formation of tissueengineered cartilage: A step towards exploring a potential use of matrix-induced cell therapy. Tissue and Cell. 2010; 42(5): 282-292

9. Munirah S, Samsudin OC, Chen HC, Sharifah Salmah SH, Aminuddin BS, Ruszymah BHI. Articular cartilage restoration in load-bearing osteochondral defects by implantation of autologous chondrocyte-fibrin constructs. The Journal of Bone \& Joint Surgery. 2007; 89(8): 1099-1109

10. Chua AWC, Khoo YC, Tan BK, Tan KC, Foo CL, Chong SJ. Skin tissue engineering advances in severe burns: review and therapeutic applications. Burns \& Trauma. 2016; 4(3): 1-14

11. Metcalfe $A D$, Ferguson MWJ. Tissue engineering of replacement skin: the crossroads of biomaterials, wound healing, embryonic development, stem cells and regeneration. Journal of The Royal Society Interface. 2007; 4(14): 413-437

12. Amini AR, Laurencin CT, Nukavarapu SP. Bone Tissue Engineering: Recent Advances and Challenges. Critical Reviews in Biomedical Engineering. 2012; 40(5): 363-408

13. Wang T, Upponi JR, Torchilin VP. Design of multifunctional non-viral gene vectors to overcome physiological barriers: Dilemmas and strategies. International Journal of Pharmaceutics. 2012; 427(1): 3-20

14. Veerapen K, Wigley RD, Valkenburg H. Musculoskeletal Pain in Malaysia: A COPCORD Survey. The Journal Rheumatology. 2007; 34(1): 207-213

15. Sha'ban M, Saim AB, Cassim SO, Hui CK, Hussein $\mathrm{FN}, \mathrm{Hj}$ Idrus RB. The Re-Expression of Collagen Type II, Aggrecan and Sox9 in TissueEngineered Human Articular Cartilage. Tissue Engineering and Regenerative Medicine. 2005; 2(4): 347-355

16. Deniz D. In The Young Researchers View, Vision Research [online]. Available at:

http: / /www.visionresearch.eu/index.php?id=906. Accessed May 5, 2017

17. Vannucci L, Lai M, Chiuppesi F, Ceccherini-Nelli L, Pistello M. Viral vectors: a look back and ahead on gene transfer technology. New Microbiologica. 2013; 36(1): 1-22

18. Al-Dosari MS, Gao X. Nonviral Gene Delivery: Principle, Limitations, and Recent Progress.
The American Association of Pharmaceutical Scientists Journal. 2009; 11(4): 671-681

19. Yazaki Y, Oyane A, Araki H, Sogo Y, Ito A, Yamazaki A, Tsurushima H. Fabrication of DNAantibody-apatite composite layers for celltargeted gene transfer. Science and Technology of Advance Materials. 2012; 13(6), 064204. http://doi.org/10.1088/14686996/13/6/064204

20. Ramamoorth $M$, Narvekar A. Non Viral Vectors in Gene Therapy- An Overview. Journal of Clinical and Diagnostic Research. 2015; 9(1): GE01-GE06

21. Fornaguera C, Grijalvo S, Galán M, FuentesPaniagua E, de la Mata FJ, Gómez R, Eritja R, Calderó G, Solans C. Novel non-viral gene delivery systems composed of carbosilanedendron functionalized nanoparticles prepared from nano-emulsions as non-viral carriers for antisense oligonucleotides. International Journal of Pharmaceutics. 2015; 478(1): 113-123

22. Yao L, Yao S, Daly W, Hendry W, Windebank A, Pandit A. Non-viral Gene Therapy for Spinal Cord Regeneration. Drug Discovery Today. 2012; 17: 999-1005

23. Sha'ban M, Cassim SO, Mohd Yahya NH, Saim $\mathrm{AB}, \mathrm{Hj}$ Idrus RB. Sox-9 Transient Transfection Enhances Chondrogenic Expression of Osteoarthritic Human Articular Chondrocytes In Vitro: Preliminary Analysis. Tissue Engineering and Regenerative Medicine. 2011; 8(1): 32-41

24. Maruyama H, Ataka K, Higuchi N, Sakamoto F, Gejyo F, Miyazaki J. Skin-targeted gene transfer using in vivo electroporation. Gene Therapy. 2001; 8(23): 1808-1812

25. Hui CK, Idrus R, Saim A. Growing Human Chondrocytes and Cartilage Tissue Engineering: Development of Economic and Optimum Human Chondrocyte Growth Medium and Cartilage Regeneration for Clinical Application. 2010. VDM Verlag Dr. Müller. ISBN-10: 3639262468 ISBN-13: 978-3639262469, 156 pages

26. Md Nazir N, Mohammad MY, Ahmad Radzi MA, Hashim R, Mat Nawi NF, Zulkifly AH, Khalid KA, Zainol I, Zamli Z, Sha'ban M. Identifying Transfection Efficiency and Cartilaginous Markers Expression in Chondrocytes Overexpressed with SRY(Sex Determining Region Y)-Box 9 (SOX9) Gene: A Preliminary Analysis in An In Vitro Model. Proceedings of the International Conference Biotechnology Engineering, ICBioE '16, July 25-27, 2016, Kuala Lumpur, Malaysia. ISBN: 978-983-429788-6. 2006; 106-109

27. Mohamad Sukri N, Ahmad Radzi MA, Abdul Rahman R, Zulkifly AH, Abdulahi Hashi A, Sha'ban M. Identifying the potential of transcription factor Sox9 gene transfer in chondrocytes differentiation and articular cartilage formation in vitro. Jurnal Teknologi. 2015; 77(25): 107-113

28. Abdul Rahman R, Ahmad Radzi MA, Mohamad Sukri N, Md Nazir N, Sha'ban M. Tissue Engineering of Articular Cartilage: From Bench 
to Bed-side. Tissue Engineering and

Regenerative Medicine. 2015; 12(1): 1-11

29. Frisch J, Rey-Rico A, Venkatesan JK, Schmitt G, Madry $\mathrm{H}$, Cucchiarini M. TGF- $B$ gene transfer and overexpression via rAAV vectors stimulates chondrogenic events in human bone marrow aspirates. Journal of Cellular and Molecular Medicine. 2016; 20(3): 430-440

30. Griffin DJ, Ortved KF, Nixon AJ, Bonnasar LJ. Mechanical Properties and Structure-Function Relationships in Articular Cartilage Repaired Using IGF-I Gene-Enhanced Chondrocytes. Journal of Orthopaedics Research. 2016; 34(1): 149-153

31. Bergeson ER. The Ethics of Gene Therapy [online]. Available at:

https://www.ndsu.edu/pubweb/ mcclean/plsc $431 /$ students/bergeson.htm. Accessed September 28, 2016

32. Primum non nocere. In Wikipedia, The Free Encyclopedia [Online]. Available at: https://en.wikipedia.org/w/index.php?title=Pri mum_non_nocere\&oldid=731686121. Accessed October 2, 2016

33. Kimmelman J. Recent developments in gene transfer: risk and ethics. BMJ. 2005; 330(7482): 79-82 University of Western Ontario. No two of us are alike -- even identical twins: Pinpointing genetic determinants of schizophrenia. Science Daily [online]. Available at:

www.sciencedaily.com/releases/2011/03/1103 28151740.htm. Accessed October 2, 2016

34. Rahman RA, Sulaiman NA, Hashi AA, Rashidi NM, Sha'ban M. Bioethical Issues on Tissue Engineering and Regenerative Medicine: A Preliminary Review from Islamic Perspective. Revelation ad Science. 2014; 4(2): 48-56

35. Omer S. The Beauty of Allah's Creation [online]. Available at:

http://www.islamicity.org/8028/the-beautyof-allahs-creation/. Accessed September 28, 2016

36. Abdul Rahman CA, Ahmed E. (n.d.). Islamic Code of Medical Professional Ethics in Islamic medicine. Shahid Athar (Ed.) [online].

Available at:

http://teachislam.com/dmdocuments/33/BOO $\mathrm{K} /$ Islamic\%20Medicine.pdf. Accessed October 2, 2016

37. Omar Hasan Kasule. MAQASID AND QAWAID AS CORE VALUES IN MEDICAL PRACTICE. Presented at a seminar on 'Islamic Healthcare' held at the Faculty of Medicine International Islamic University Malaysia 18-19 December 2010 [online]. Available at: http://omarkasuletib.blogspot.my/2011/08/101218l-maqasidand-qawaid-as-core.html. Accessed October 2, 2016.

38. Saraf A, Mikos AG. Gene delivery strategies for cartilage tissue engineering. Advance Drug Delivery Reviews. 2006; 58(4): 592-603

39. Mohd Yusof M, Zainul Ibrahim Z, Munirah S. The application of tissue engineering in degenerative disc disease: An Islamic perspective. Regenerative Research. 2014;
3(1): 41-51

40. Management of Osteoarthritis (Second Edition). In Clinical Practice Guideline [online].

Available at:

http://www.moh.gov.my/index.php/file _manager/dl_item/625746726248567459585167 6447567961326c7561533945636d466d644639445 $5456466543045756347526 d$. Accessed May 5, 2017

41. Munirah S, Zainul Ibrahim Z, Rozlin AR, Mohd Yusof $M$, Norhamiza MS, Noorhidayah MN, M. Aa'zamuddin AR. Exploring the Islamic Perspective on Tissue Engineering Principles and Practice. Global Journal Al-Thaqafah. 2014; 4(2): 29-40

42. Pathan MSK. Every Illness Has A cure: The Islamic Perspective [online]. Available at: http: //www.fiqh.org/2009/04/every-illnesshas-a-cure-the-islamic-perspective/. Accessed September 28, 2016

43. Abdullah YA. The Holy Qur'an: Text and Translation. The Other Press. 2009.

44. Hammond HK, Penny WF, Traverse JH, Henry TD, Watkins MW, Yancy CW, Sweis RN, Adler ED, Patel AN, Murray DR, Ross RS, Bhargava V, Maisel A, Barnard DD, Lai NC, Dalton ND, Lee ML, Narayan SM, Blanchard DG, Gao MH. Intracoronary Gene Transfer of Adenylyl Cyclase 6 in Patients With Heart Failure. JAMA Cardiology. 2016; 1(2): 163-171 